\title{
Interdependencies among ethylene oxidation and chlorine moderation catalytic cycles over promoted
}

\author{
$\mathrm{Ag} / \alpha-\mathrm{Al}_{2} \mathrm{O}_{3}$ catalysts
}

\author{
Krishna R. Iyer ${ }^{1 *}$ and Aditya Bhan ${ }^{1 *}$ \\ ${ }^{1}$ Department of Chemical Engineering and Materials Science, University of Minnesota, \\ Minneapolis, Minnesota, 55455, USA \\ *abhan@umn.edu
}

*iyer0040@umn.edu 


\section{S.1. Determination of surface concentration of Ag sites}

Procedure: $0.505 \mathrm{~g}$ of promoted $\mathrm{Ag} / \alpha-\mathrm{Al}_{2} \mathrm{O}_{3}$ catalyst was reduced in flowing $\mathrm{H}_{2}\left(\right.$ at $1 \mathrm{~cm}^{3} \mathrm{~s}^{-1}$ ) for $20 \mathrm{~h}$ at $513 \mathrm{~K}$. It was then cooled to $443 \mathrm{~K}$ in flowing $\mathrm{H}_{2}\left(\right.$ at $\left.1 \mathrm{~cm}^{3} \mathrm{~s}^{-1}\right)$. After purging out all the $\mathrm{H}_{2}$ from the reactor, $\mathrm{He}$ was recirculated at $130 \mathrm{kPa}$ inside the batch reactor. Then, a pulse containing $16.12 \mu \mathrm{mol}$ of $\mathrm{N}_{2} \mathrm{O}$ from a $0.5 \mathrm{~cm}^{3}$ sample loop was injected into the reactor. The same procedure was repeated with a blank reactor.

Every GC peak area corresponds to a concentration of $\mathrm{N}_{2} \mathrm{O}$ which can be separately determined by a calibration curve. Therefore, we obtain concentration of $\mathrm{N}_{2} \mathrm{O}$ as a function of time during the two batch reactions (with catalyst/ blank reactor). Moreover, the first injection for both reactions with and without catalyst was taken at the same time (120 s after pulsing $\mathrm{N}_{2} \mathrm{O}$ ).

Total reactor volume $=33 \mathrm{~cm}^{3}$

Moles consumed after $120 \mathrm{~s}$ (at the first GC injection $)=(\mathrm{C} 1-\mathrm{C} 2) * 33 \mathrm{~cm}^{3}$

$\mathrm{C} 1=$ concentration of $\mathrm{N}_{2} \mathrm{O}$ at the first $\mathrm{GC}$ injection in the case without catalyst

$\mathrm{C} 2=$ concentration of $\mathrm{N}_{2} \mathrm{O}$ at the first $\mathrm{GC}$ injection in the case with catalyst

Henceforth,

Moles consumed at the $\mathrm{i}^{\text {th }} \mathrm{GC}$ injection $=\mathrm{N}_{\mathrm{i}-1}-\mathrm{N}_{\mathrm{dil}}+\mathrm{N}_{\mathrm{act}}$

$\mathrm{N}_{\mathrm{i}-1}$ - Moles consumed till the preceding injection

$\mathrm{N}_{\text {dil }}$ - Moles that would have been lost due to sample withdrawal for GC injection $\mathrm{N}_{\text {act }}$ - Moles that adsorbed on the catalyst + those that were lost due to sample withdrawal for GC injection

$\mathrm{N}_{\mathrm{dil}}$ can be calculated using the blank reactor concentration vs. time data. 
If $\mathrm{C}_{\mathrm{i}-1}, \mathrm{C}_{\mathrm{i}}, \mathrm{C}_{\mathrm{i}}$ ' are $\mathrm{N}_{2} \mathrm{O}$ concentrations at the $(\mathrm{i}-1)^{\text {th }}$ injection, $\mathrm{N}_{2} \mathrm{O}$ concentration at the $\mathrm{i}^{\text {th }}$ injection without catalyst, and $\mathrm{N}_{2} \mathrm{O}$ concentration at the $\mathrm{i}^{\text {th }}$ injection with catalyst, respectively then

Moles of $\mathrm{N}_{2} \mathrm{O}$ consumed during the blank reaction $-\left(\mathrm{C}_{\left.\mathrm{i}-1-\mathrm{C}_{\mathrm{i}}\right)}\right) 33 \mathrm{~cm}^{3}=\mathrm{N}_{\mathrm{dil}}$

Moles of $\mathrm{N}_{2} \mathrm{O}$ consumed during the reaction with catalyst $-\left(\mathrm{C}_{\mathrm{i}-1-1}-\mathrm{C}_{\mathrm{i}}{ }^{\prime}\right) * 33 \mathrm{~cm}^{3}=\mathrm{N}_{\mathrm{act}}$

Moles consumed at the $\mathrm{i}^{\text {th }} \mathrm{GC}$ injection $=\mathrm{N}_{\mathrm{i}-1}-\mathrm{N}_{\mathrm{dil}}+\mathrm{N}_{\text {act }}$

At the completion of the batch reaction, $\mathrm{N}_{\mathrm{dil}}$ and $\mathrm{N}_{\mathrm{act}}$ become equal implying no further reaction. This allows us to calculate the total moles of $\mathrm{N}_{2} \mathrm{O}$ consumed during the batch reaction.

\section{Calculations:}

Total $\mathrm{N}_{2} \mathrm{O}$ consumed $=6.194 \mu \mathrm{mol}$

Using 1:1 Ag:O stoichiometry,

Mass of surface $\mathrm{Ag}=$ Total $\mathrm{N}_{2} \mathrm{O}$ moles consumed $\times$ molecular weight of $\mathrm{Ag}$

$$
=6.194 \times 107.86=0.668 \mathrm{mg}
$$

Total mass of Ag $=\mathrm{Ag}$ weight loading $\times$ mass of catalyst loaded during reaction

$$
=0.358 \times 504.8=180.72 \mathrm{mg}
$$

Ag surface dispersion $\left(\operatorname{disp}_{\mathrm{Ag}}\right)=\frac{\text { Mass of surface } \mathrm{Ag} \text { in the catalyst }}{\text { Total mass of Ag in the catalyst }} \times 100$

$$
=\frac{0.668}{180.718} \times 100=\mathbf{0 . 3 7 \%}
$$

The average Ag particle size $\left(\mathrm{d}_{\mathrm{Ag}}\right)$ can be calculated by assuming $\operatorname{Ag}(111)$ to be the exposed surface of the catalyst. 


$$
\mathrm{d}_{\mathrm{Ag}}=\frac{6 \rho_{\mathrm{Ag}(111)}}{\operatorname{disp}_{\mathrm{Ag}} \rho_{\mathrm{Ag}}}
$$

$\rho_{\mathrm{Ag}(111)}=$ Atomic mass density of $\operatorname{Ag}(111)$ surface $=2.49 \times 10^{-21} \mathrm{~g} \mathrm{~nm}^{-2}(1)$

$$
\begin{gathered}
\rho_{\mathrm{Ag}}=\text { Bulk density of silver }=10.49 \mathrm{~g} \mathrm{~cm}^{-3}(2) \\
\mathrm{d}_{\mathrm{Ag}}=\frac{6 \times 2.49 \times 10^{-21}}{0.0037 \times 10.49 \times 10^{-21}} \\
\mathrm{~d}_{\mathrm{Ag}}=384.92 \mathrm{~nm}
\end{gathered}
$$

\section{S.2. Particle scale heat and mass transport}

The reaction conditions employed during the study of kinetics of ethylene epoxidation over the non-porous promoted silver catalysts were assessed using the GradientCheck tool developed by Hickman et al. (3) to ensure there are no external heat and mass transfer limitations that corrupt intrinsic rate measurements. The following process conditions were tested for heat and mass transfer limitations:

Table S.1. Parameters used to estimate the heat and mass transfer limitations at the following reaction conditions: $30 \mathrm{~mol} \% \mathrm{C}_{2} \mathrm{H}_{4}, 5.3 \mathrm{~mol} \% \mathrm{O}_{2}, 1 \mathrm{~mol} \% \mathrm{CO}_{2}$, balance He; flowrate $=2.78 \mathrm{~cm}^{3} \mathrm{~s}^{-1}$; catalyst mass $=0.035 \mathrm{~g}$ promoted $\mathrm{Ag} / \alpha-\mathrm{Al} 2 \mathrm{O} 3$. EO selectivity of $85 \%$ was assumed to calculate the heat of reaction.

\begin{tabular}{|c|c|c|}
\hline Parameter & Value & Units \\
\hline Temperature & 513 & $\mathrm{~K}$ \\
\hline Total pressure & 5.3 & $\mathrm{~m}$ \\
\hline Reactor radius & $2.25 \times 10^{-3}$ & $\mathrm{~m}$ \\
\hline Bed length & $2.90 \times 10^{-3}$ & $\mathrm{~m}$ \\
\hline Particle radius & $1.64 \times 10^{-4}$ & $\mathrm{~mol} \mathrm{~kg} \mathrm{cat}^{-1} \mathrm{~s}^{-1}$ \\
\hline Reaction rate & 0.01 & $\mathrm{~kJ} \mathrm{~mol}^{-1}$ \\
\hline Heat of reaction & -288.3 & \\
\hline
\end{tabular}




\begin{tabular}{|c|c|c|}
\hline Ethylene conversion & 1 & $\%$ \\
\hline Catalyst bulk density & 931.8 & $\mathrm{~kg} \mathrm{~m}^{-3}$ \\
\hline Catalyst thermal conductivity & 0.2 & $\mathrm{~W} \mathrm{~m}^{-1} \mathrm{~K}^{-1}$ \\
\hline Catalyst surface area & 1.25 & $\mathrm{~m}^{2} \mathrm{~g}^{-1}$ \\
\hline Catalyst pore volume & $5 \times 10^{-7}$ & $\mathrm{~m}^{3} \mathrm{~g}^{-1}$ \\
\hline
\end{tabular}

The temperature and concentration profiles between the catalyst particle and the bulk gas phase for the parameters enlisted in Table S.1 are shown in Figure S.1. Negligible concentration and temperature gradients are noted from this analysis suggesting that the chosen process conditions ensure measurement of intrinsic kinetic rate measurements at isothermal conditions.

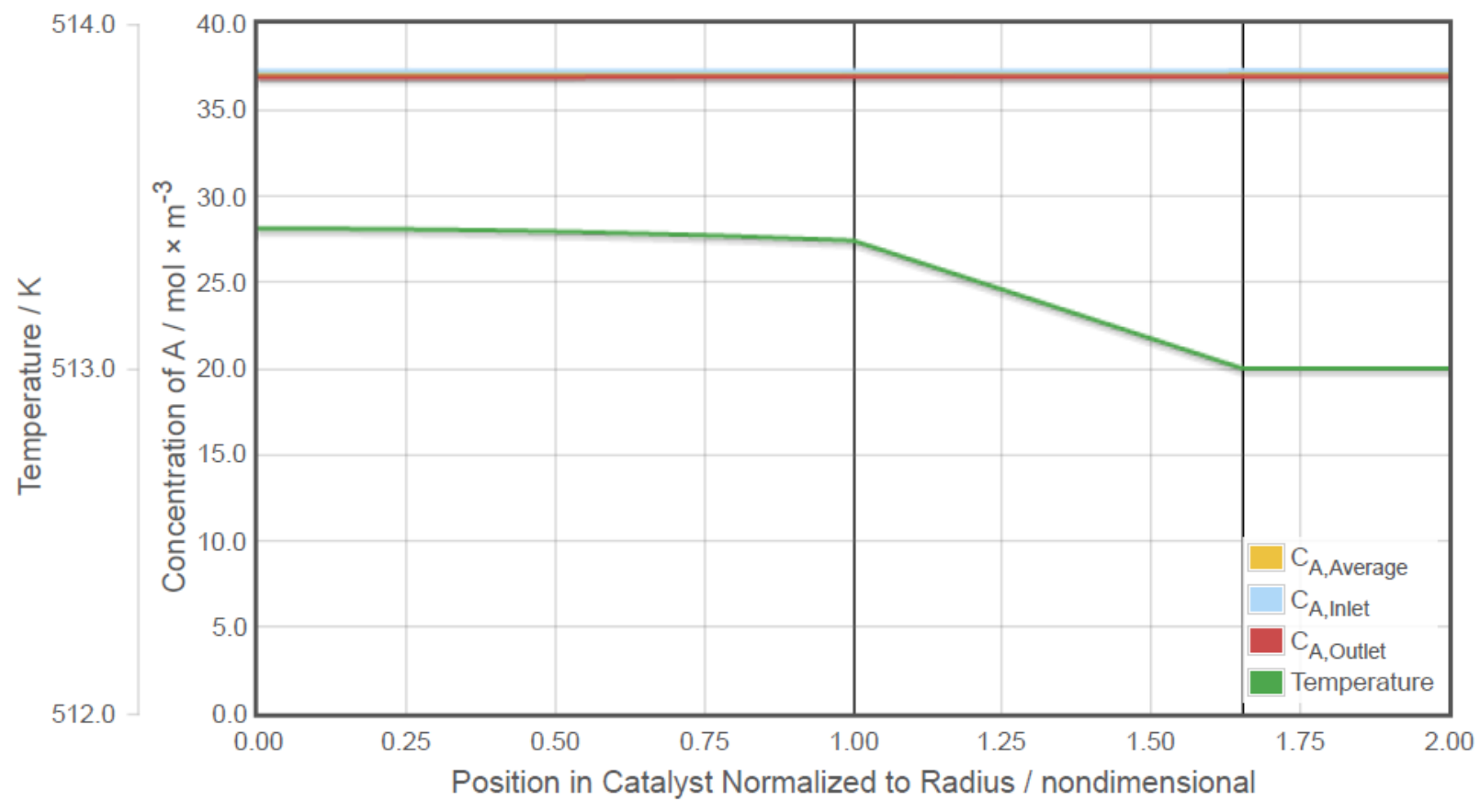

Figure S.1. Temperature and concentration profiles between the catalyst particle and the bulk gas phase for the process conditions listed in Table S.1.

\section{S.3. Transient EO formation rate}

EO rates measured as a function of time on stream at a particular reaction condition are shown in Figure S.2. The catalyst evolves under the flow of the reactant stream for about 18 hours 
before reaching a steady state rate most likely due to catalyst restructuring as proposed by van Hoof et al. (4)

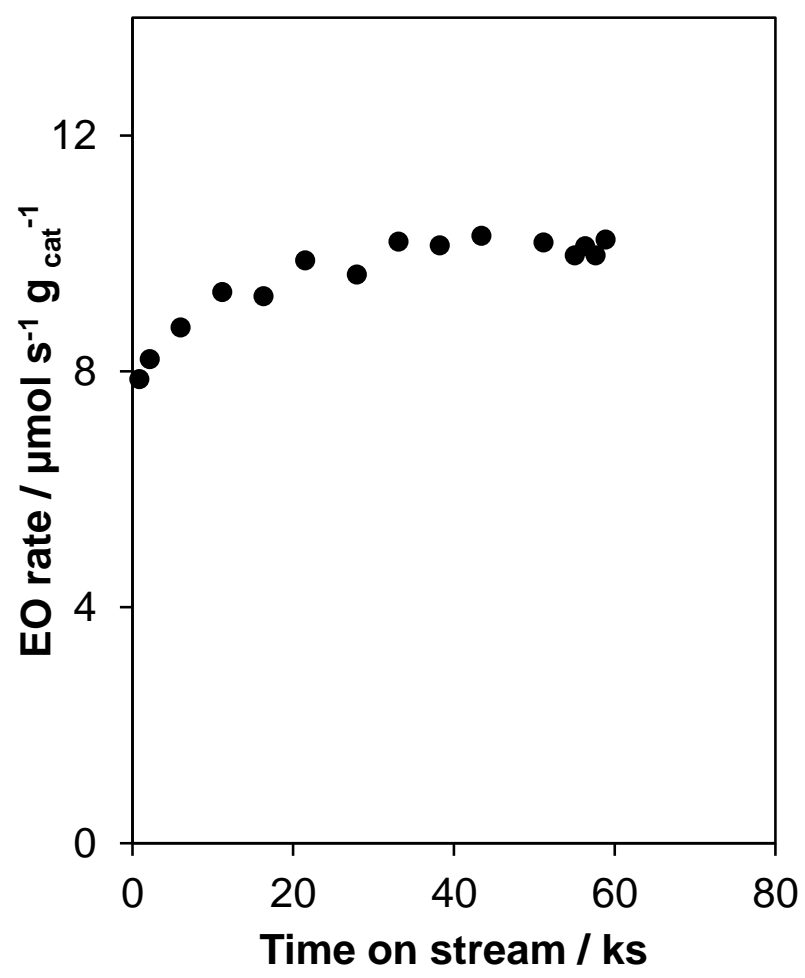

Figure S.2. EO formation rate measured as a function of time on stream. Conditions: $30 \mathrm{~mol} \% \mathrm{C}_{2} \mathrm{H}_{4}, 5.3$ $\mathrm{mol} \% \mathrm{O}_{2}, 0.4 \mathrm{~mol}_{0} \mathrm{C}_{2} \mathrm{H}_{6}, 6.5 \mathrm{ppm} \mathrm{C}_{2} \mathrm{H}_{5} \mathrm{Cl}, 1 \mathrm{~mol} \% \mathrm{CO}_{2}$; catalyst mass $=0.0455 \mathrm{~g}_{\text {promoted Ag} / \alpha-\mathrm{Al} 2 \mathrm{O} 3}$; flowrate $=2.78 \mathrm{~cm}^{3} \mathrm{~s}^{-1}$; space velocity $=61.73 \mathrm{~cm}^{3} \mathrm{~s}^{-1} \mathrm{~cm}^{-3}$ cat; $513 \mathrm{~K} ; 5.3$ bar.

\section{S.4. Measurement of surface chlorine coverage}

The surface coverage of chlorine is calculated by first allowing the promoted catalyst to reach a steady state under reaction conditions in a flow reactor ( $18 \mathrm{~h}$ time on-stream) followed by recirculating a mixture of ethane and oxygen in a batch reactor to remove adsorbed chlorine in the form of ethyl chloride; the assessed value is then normalized by the moles of surface silver to determine the fractional chlorine coverage. The recirculation protocol was repeated four times as all the adsorbed chlorine is not removed in one removal cycle and the amount of chlorine removed 
after successive recirculation experiments was fitted with a power law model to yield a parameter (-2.3) which is invariant across a range of steady state reaction conditions (Figure S.3). The total chlorine content of the catalyst after $18 \mathrm{~h}$ on-stream was assessed by measuring the chlorine removed in one recirculation cycle and extrapolating to infinite removal cycles using the power law model fitted parameter.

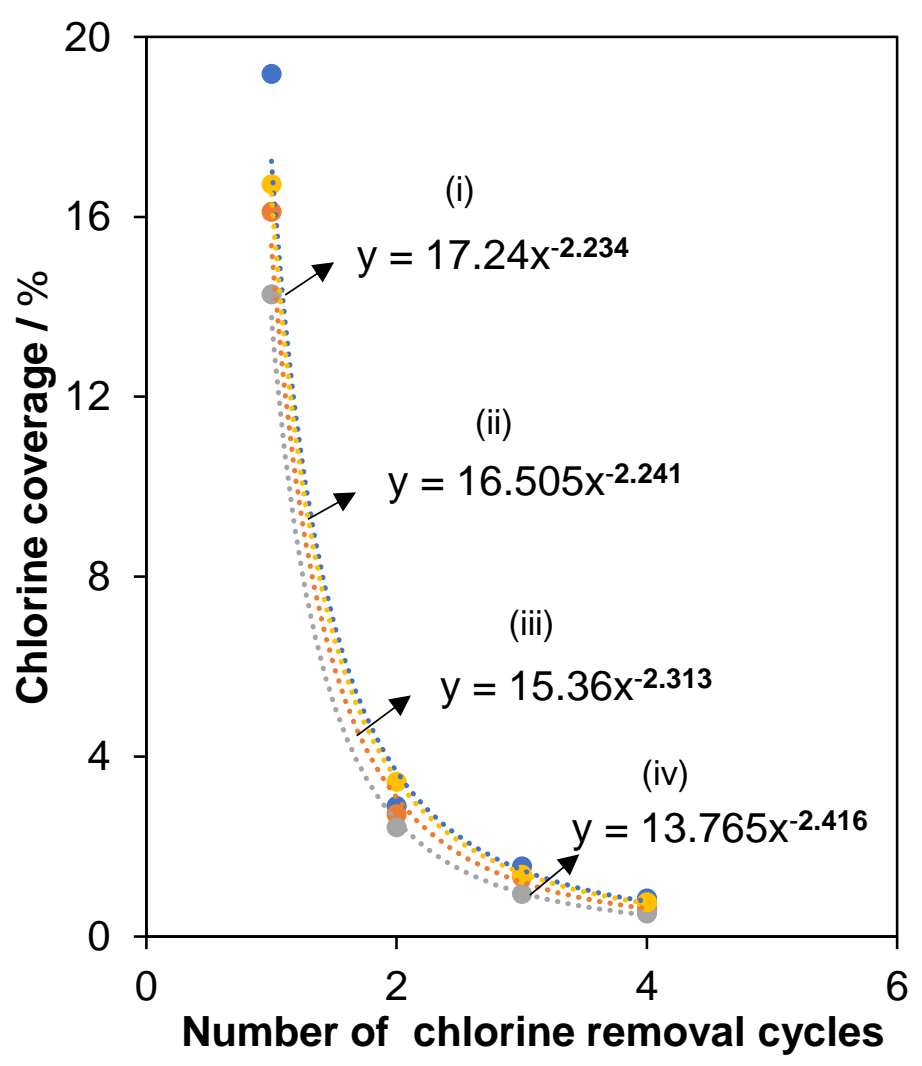

Figure S.3. Chlorine coverage measured after each chlorine removal cycle in a recirculating batch reactor. $18 \mathrm{~h}$ steady state conditions: $30 \mathrm{~mol} \% \mathrm{C}_{2} \mathrm{H}_{4}, 1 \mathrm{~mol} \% \mathrm{CO}_{2}$, (i) $7.7 \mathrm{~mol} \% \mathrm{O}_{2}, 0.27 \mathrm{~mol} \% \mathrm{C}_{2} \mathrm{H}_{6}, 7.2 \mathrm{ppm}$ $\mathrm{C}_{2} \mathrm{H}_{5} \mathrm{Cl}$, (ii) $5.3 \mathrm{~mol} \% \mathrm{O}_{2}, 0.4 \mathrm{~mol} \% \mathrm{C}_{2} \mathrm{H}_{6}, 5.5 \mathrm{ppm} \mathrm{C}_{2} \mathrm{H}_{5} \mathrm{Cl}$, (iii) $3 \mathrm{~mol} \% \mathrm{O}_{2}, 0.4 \mathrm{~mol} \% \mathrm{C}_{2} \mathrm{H}_{6}, 4.5 \mathrm{ppm}$ $\mathrm{C}_{2} \mathrm{H}_{5} \mathrm{Cl}$ balance $\mathrm{He}$ (iv) $5.3 \mathrm{~mol} \% \mathrm{O}_{2}, 0.33 \mathrm{~mol} \% \mathrm{C}_{2} \mathrm{H}_{6}, 6.8$ ppm $\mathrm{C}_{2} \mathrm{H}_{5} \mathrm{Cl} ; 5.3$ bar; $513 \mathrm{~K}$; space velocity = $61.73 \mathrm{~cm}^{3} \mathrm{~s}^{-1} \mathrm{~cm}^{-3}$ cat; catalyst mass $=0.045 \mathrm{~g}_{\text {promoted } \mathrm{Ag} / \alpha-\mathrm{Al} 2 \mathrm{O} 3}$; flow rate $=2.78 \mathrm{~cm}^{3} \mathrm{~s}^{-1}$; followed by chlorine counting in a recirculating batch reactor using $9.1 \mathrm{~mol} \% \mathrm{C}_{2} \mathrm{H}_{6}, 0.1 \mathrm{~mol} \% \mathrm{CH}_{4}, 3 \mathrm{~mol} \% \mathrm{O}_{2}$ mixture at 513 $\mathrm{K}$ and $130 \mathrm{kPa}$. Lines represent power law model fits.

\section{S.5 Errors in measurement of reaction orders for $\mathrm{EO}$ and $\mathrm{CO}_{2}$ formation rates}


The uncertainties in the oxygen, ethylene, and $\mathrm{CO}_{2}$ reaction orders for $\mathrm{EO}$ and $\mathrm{CO}_{2}$ formation rates are reported in Figures S.4, Figure S.5, and Figure S.6 respectively.
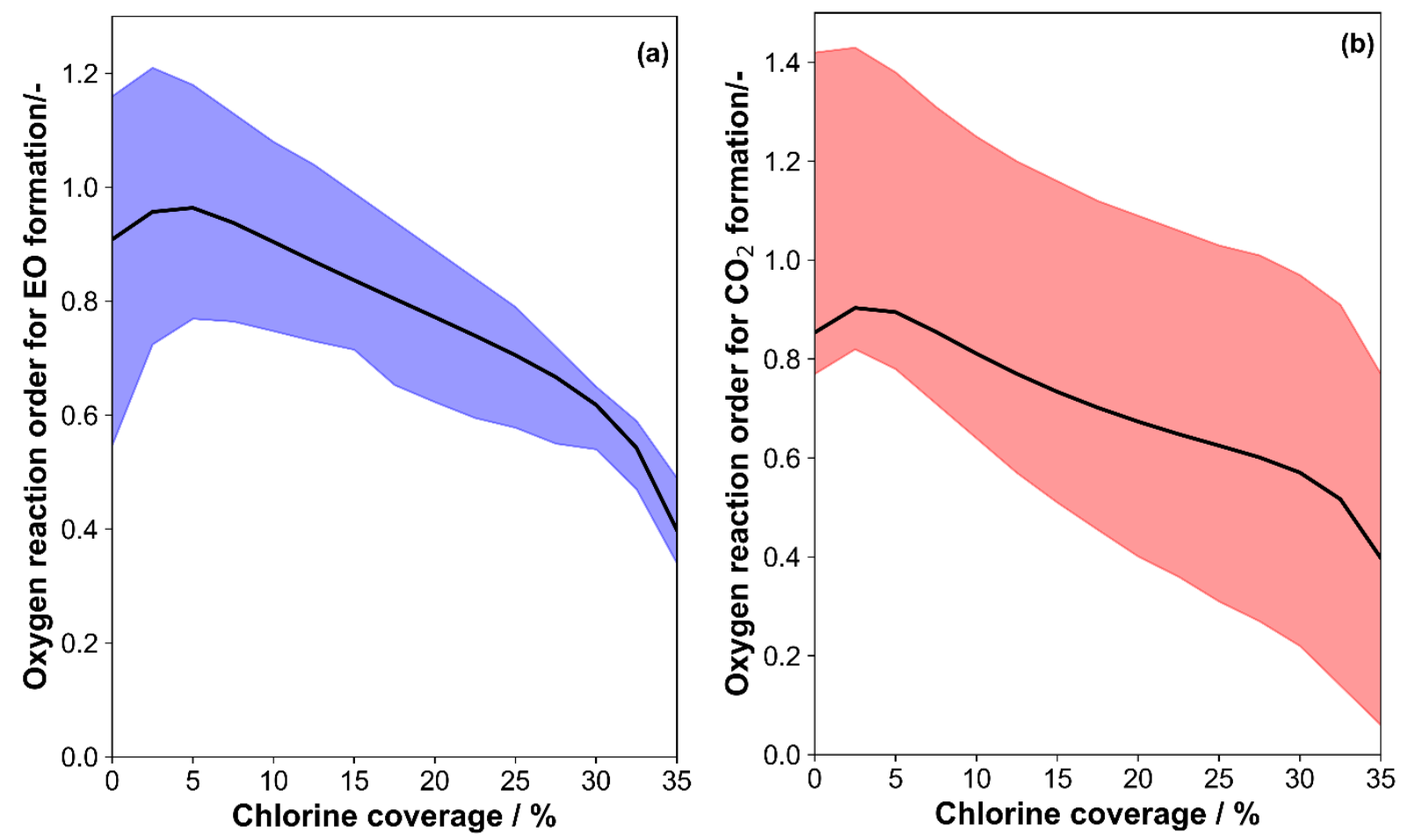

Figure S.4. Oxygen reaction order for (a) $\mathrm{EO}$ and (b) $\mathrm{CO}_{2}$ formation measured as a function of chlorine coverage. The blue and red shaded regions indicate the uncertainties in the reaction orders for $\mathrm{EO}$, and $\mathrm{CO}_{2}$ formation respectively based on the $95 \%$ confidence intervals. Steady state conditions: $3-7.7 \mathrm{~mol} \% \mathrm{O}_{2}, 30$ mol $\% \mathrm{C}_{2} \mathrm{H}_{4}, 1 \mathrm{~mol} \% \mathrm{CO}_{2}, 0-8.8 \mathrm{ppm} \mathrm{C}_{2} \mathrm{H}_{5} \mathrm{Cl}, 0.2-2 \mathrm{~mol} \% \mathrm{C}_{2} \mathrm{H}_{6}$, balance $\mathrm{He} ; 5.3$ bar; $513 \mathrm{~K}$; space velocity $=61.73\left(3,5.3 \mathrm{~mol} \% \mathrm{O}_{2}\right)$ and $79.37\left(7.7 \mathrm{~mol}_{0} \mathrm{O}_{2}\right) \mathrm{cm}^{3} \mathrm{~s}^{-1} \mathrm{~cm}^{-3}$ cat; flow rate $=2.78 \mathrm{~cm}^{3} \mathrm{~s}^{-1}$; catalyst mass $=$

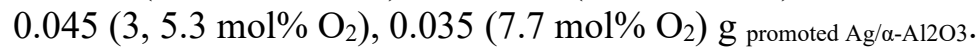



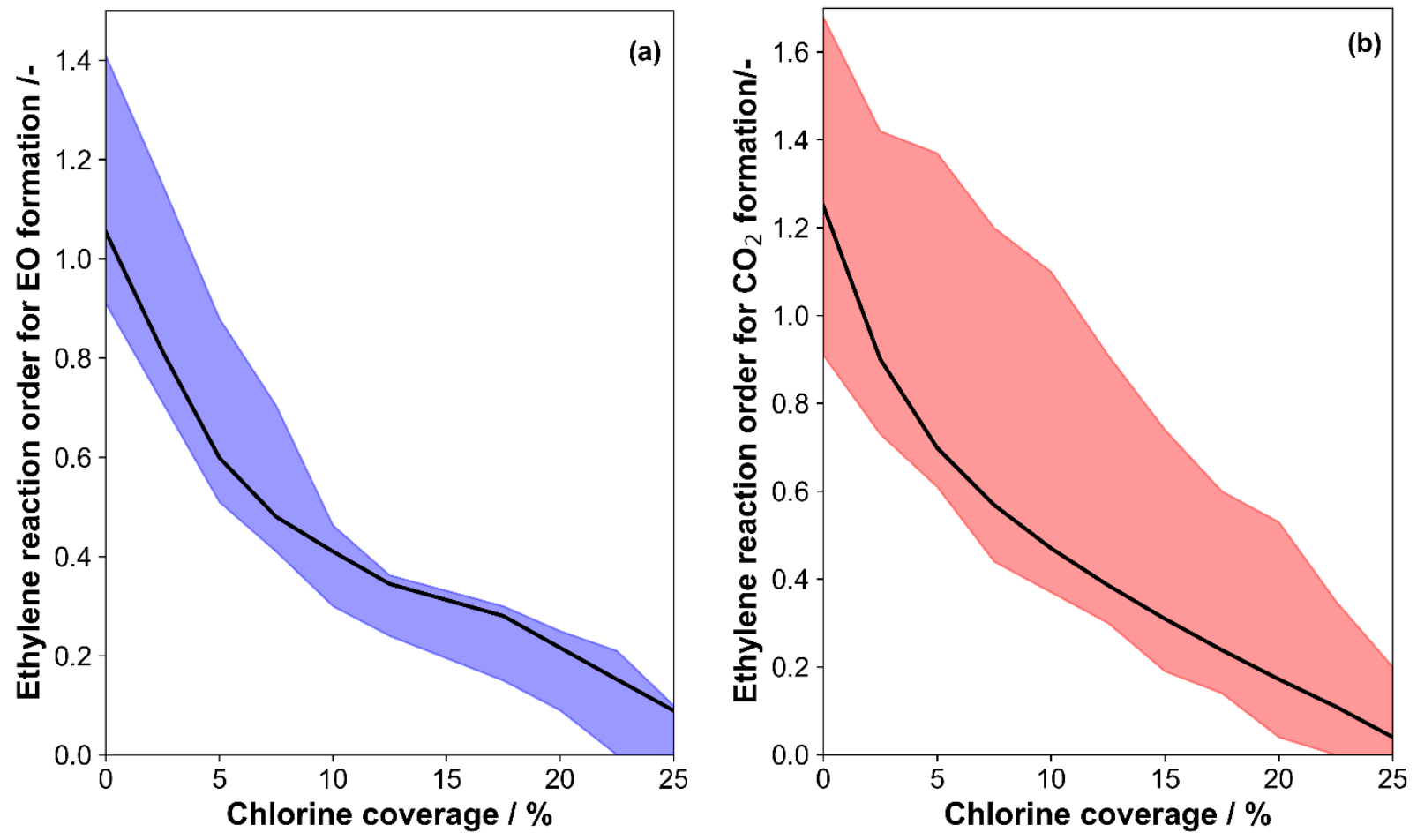

Figure S.5. Ethylene reaction order for (a) $\mathrm{EO}$ and (b) $\mathrm{CO}_{2}$ formation measured as a function of chlorine coverage. The blue and red shaded regions indicate the uncertainties in the reaction orders for $\mathrm{EO}$, and $\mathrm{CO}_{2}$ formation respectively based on the $95 \%$ confidence intervals. Steady state conditions: $20-40 \mathrm{~mol}_{0} \mathrm{C}_{2} \mathrm{H}_{4}$, $5.3 \mathrm{~mol} \% \mathrm{O}_{2}, 1 \mathrm{~mol} \% \mathrm{CO}_{2}, 0-8.8 \mathrm{ppm} \mathrm{C}_{2} \mathrm{H}_{5} \mathrm{Cl}, 0.2-2 \mathrm{~mol} \% \mathrm{C}_{2} \mathrm{H}_{6}$, balance $\mathrm{He}$ ); 5.3 bar; $513 \mathrm{~K}$; space velocity $=61.73\left(20,30 \mathrm{~mol} \% \mathrm{C}_{2} \mathrm{H}_{4}\right)$ and $79.37\left(40 \mathrm{~mol} \% \mathrm{C}_{2} \mathrm{H}_{4}\right) \mathrm{cm}^{3} \mathrm{~s}^{-1} \mathrm{~cm}^{-3}$ cat; flow rate $=2.78 \mathrm{~cm}^{3} \mathrm{~s}^{-1}$; catalyst mass $=0.045\left(20,30 \mathrm{~mol}_{0} \mathrm{C}_{2} \mathrm{H}_{4}\right), 0.035\left(40 \mathrm{~mol} \% \mathrm{C}_{2} \mathrm{H}_{4}\right) \mathrm{g}$ promoted Ag/a-Al2O3. 

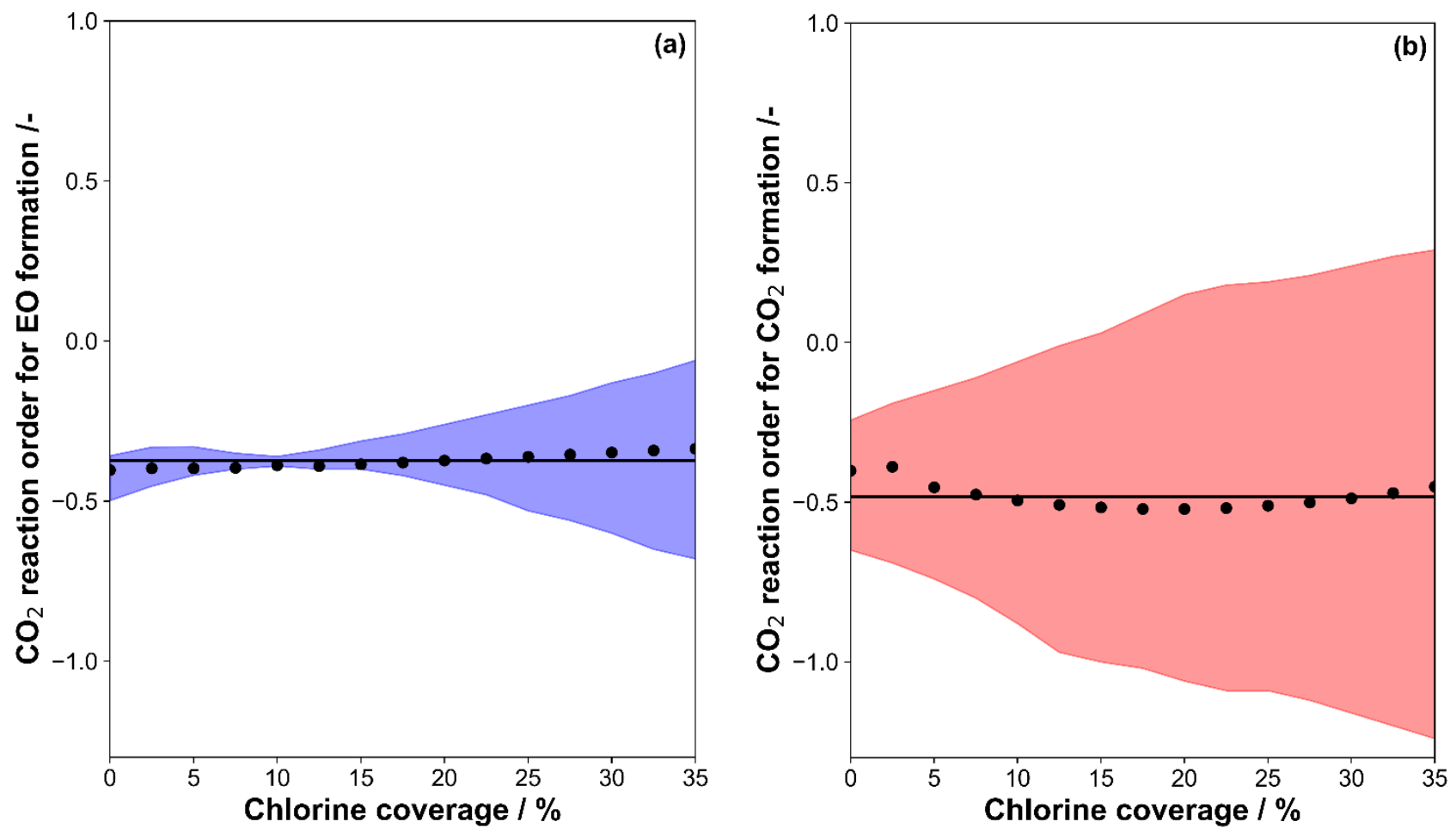

Figure S.6. $\mathrm{CO}_{2}$ reaction order for (a) $\mathrm{EO}$ and (b) $\mathrm{CO}_{2}$ formation measured as a function of chlorine coverage (The solid lines are a guide to the eye). The blue and red shaded regions indicate the uncertainties in the reaction orders for $\mathrm{EO}$, and $\mathrm{CO}_{2}$ formation respectively based on the $95 \%$ confidence intervals. Steady state conditions: $0.35-3 \mathrm{~mol} \% \mathrm{CO}_{2}, 5.3 \mathrm{~mol} \% \mathrm{O}_{2}, 30 \mathrm{~mol} \% \mathrm{C}_{2} \mathrm{H}_{4}, 0-8.8 \mathrm{ppm} \mathrm{C}_{2} \mathrm{H}_{5} \mathrm{Cl}, 0.2-2 \mathrm{~mol} \% \mathrm{C}_{2} \mathrm{H}_{6}$, balance $\mathrm{He}$; 5.3 bar; $513 \mathrm{~K}$; space velocity $=61.73\left(1,3 \mathrm{~mol} \% \mathrm{CO}_{2}\right)$ and $79.37\left(0.35 \mathrm{~mol} \% \mathrm{CO}_{2}\right) \mathrm{cm}^{3} \mathrm{~s}^{-1}$ $\mathrm{cm}^{-3}$ cat; flow rate $=2.78 \mathrm{~cm}^{3} \mathrm{~s}^{-1}$; catalyst mass $=0.045\left(1,3 \mathrm{~mol} \% \mathrm{CO}_{2}\right), 0.035\left(0.35 \mathrm{~mol} \% \mathrm{CO}_{2}\right) \mathrm{g}_{\text {promoted }}$ $\mathrm{Ag} / \alpha-\mathrm{Al} 2 \mathrm{O} 3$.

\section{S.6. Variation of EO selectivity with oxygen and ethylene pressure}

EO selectivities measured as a function of chlorine coverage at three different oxygen and ethylene pressures overlap illustrating invariance of EO selectivity with oxygen and ethylene pressure (Figure S.7). 

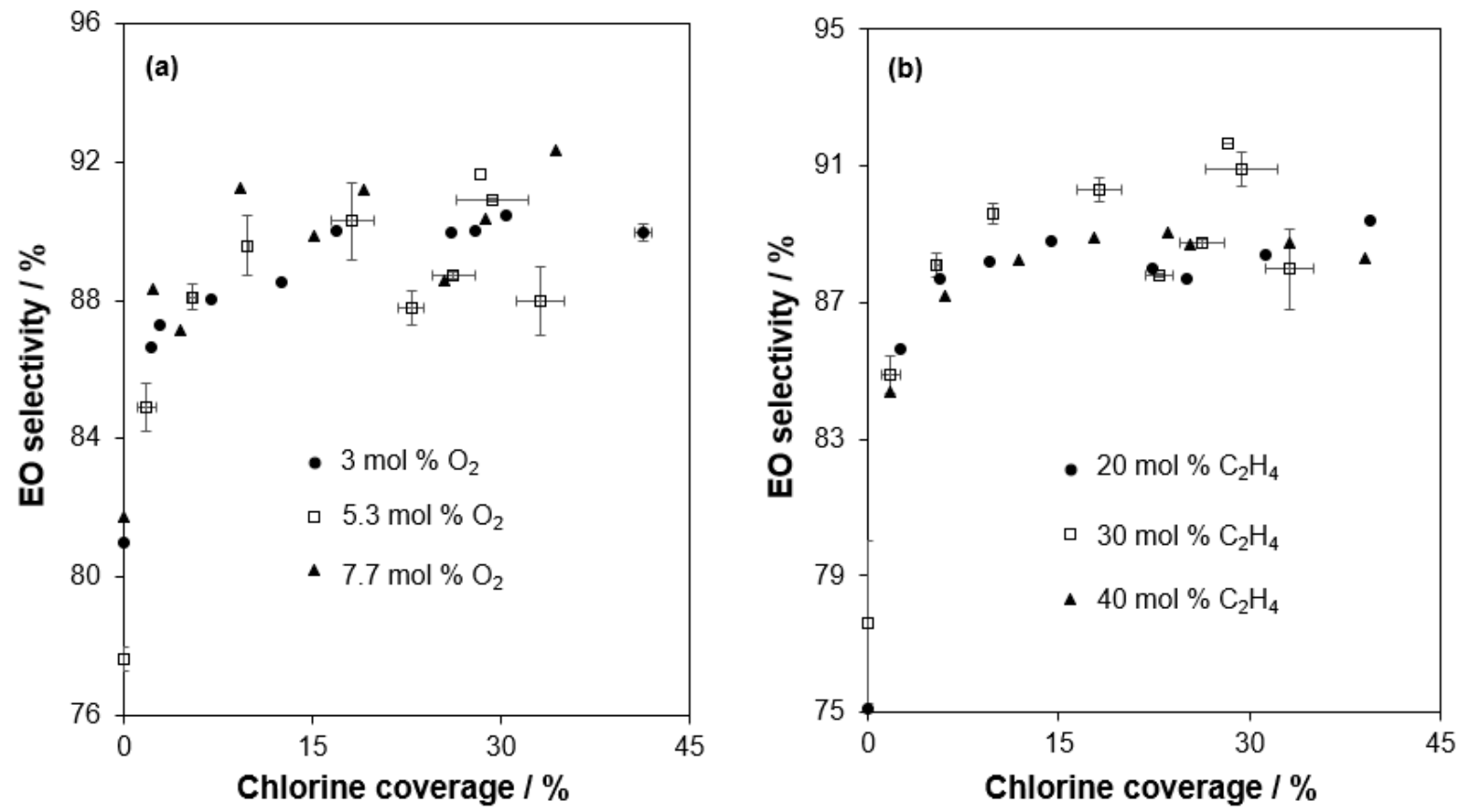

Figure S.7. EO selectivity measured as a function of chlorine coverage at different (a) oxygen pressures (b) ethylene pressures. Each data point shown is a steady state condition acquired after $18 \mathrm{~h}$ on-stream. Steady state conditions: $1 \mathrm{~mol} \% \mathrm{CO}_{2}, 0-8.8 \mathrm{ppm} \mathrm{C}_{2} \mathrm{H}_{5} \mathrm{Cl}, 0.2-2 \mathrm{~mol} \% \mathrm{C}_{2} \mathrm{H}_{6}$, (a) 3 (filled circles), 5.3 (unfilled squares), 7.7 (filled triangles) $\mathrm{mol} \% \mathrm{O}_{2}, 30 \mathrm{~mol} \% \mathrm{C}_{2} \mathrm{H}_{4}$, (b) 20 (filled circles), 30 (unfilled squares), 40 (filled triangles) $\mathrm{mol} \% \mathrm{C}_{2} \mathrm{H}_{4}, 5.3 \mathrm{~mol} \% \mathrm{O}_{2}$, balance $\mathrm{He}$; $5.3 \mathrm{bar} ; 513 \mathrm{~K}$; space velocity $=61.73$ $\left(3,5.3 \mathrm{~mol} \% \mathrm{O}_{2}\right.$ and $\left.20,30 \mathrm{~mol} \% \mathrm{C}_{2} \mathrm{H}_{4}\right)$ and $79.37\left(7.7 \mathrm{~mol} \% \mathrm{O}_{2}, 40 \mathrm{~mol} \% \mathrm{C}_{2} \mathrm{H}_{4}\right) \mathrm{cm}^{3} \mathrm{~s}^{-1} \mathrm{~cm}^{-3}$ cat; flow rate $=2.78 \mathrm{~cm}^{3} \mathrm{~s}^{-1}$; catalyst mass $=0.045\left(3,5.3 \mathrm{~mol} \% \mathrm{O}_{2}\right.$ and $\left.20,30 \mathrm{~mol} \% \mathrm{C}_{2} \mathrm{H}_{4}\right), 0.035\left(7.7 \mathrm{~mol} \% \mathrm{O}_{2}, 40\right.$ $\left.\mathrm{mol} \% \mathrm{C}_{2} \mathrm{H}_{4}\right) \mathrm{g}$ promoted $\mathrm{Ag} / \alpha-\mathrm{Al} 2 \mathrm{O} 3$.

\section{S.7. Model for prediction of the chlorine coverage - vinyl chloride and vinyl chloride/ethyl chloride mixtures}

Chlorine coverages were measured as a function of five different vinyl chloride pressures (keeping the pressures of all other reactants the same) and fitted to equation S.5 by keeping other parameters $\left(\mathrm{K}_{1} \mathrm{~K}_{2}, \mathrm{~K}_{9}, \mathrm{~K}_{10}\right.$, and $\left.\mathrm{k}_{5}\right)$ constant to determine $\mathrm{k}_{4} \mathrm{~K}_{3}$ for vinyl chloride.

$$
\theta_{\mathrm{Cl}}=\frac{\frac{\mathrm{k}_{4} \mathrm{~K}_{3} \mathrm{P}_{\mathrm{C} 2 \mathrm{H} 5 \mathrm{Cl}}}{\mathrm{k}_{5} \mathrm{P}_{\mathrm{C} 2 \mathrm{H} 6}}}{1+\mathrm{K}_{10} \mathrm{P}_{\mathrm{CO} 2} \sqrt{\mathrm{K}_{1} \mathrm{~K}_{2} \mathrm{P}_{\mathrm{O} 2}}+\mathrm{K}_{9} \mathrm{P}_{\mathrm{C} 2 \mathrm{H} 4}+\sqrt{\mathrm{K}_{1} \mathrm{~K}_{2} \mathrm{P}_{\mathrm{O} 2}}+\frac{\mathrm{k}_{4} \mathrm{~K}_{3} \mathrm{P}_{\mathrm{C} 2 \mathrm{H} 5 \mathrm{Cl}}}{\mathrm{k}_{5} \mathrm{P}_{\mathrm{C} 2 \mathrm{H} 6}}}
$$


Chlorine coverage increases with increasing vinyl chloride pressure as chlorine deposition rate is positive order in vinyl chloride pressure and the resulting trend is captured by the model as shown in Figure S.8 (a). A comparison of $\mathrm{k}_{3} \mathrm{~K}_{4}$ values of ethyl chloride and vinyl chloride (Table S.2) shows that both alkyl chlorides have similar chloriding effectiveness values within experimental error. These results are consistent with patent reports by Zhang et al. (5) and Shibata et al. (6) which assign similar chloriding effectiveness factors to ethyl chloride and vinyl chloride.

Table S.2. A comparison of chloriding effectiveness values $\left(\mathrm{k}_{4} \mathrm{~K}_{3}\right)$ for ethyl chloride and vinyl chloride.

\begin{tabular}{|c|c|c|c|}
\hline Parameter $\mathrm{k}_{4} \mathrm{~K}_{3}$ & Value & & Units \\
\hline Ethyl chloride & $\begin{array}{l}6.36 \times 10^{-2} \\
6.43 \times 10^{-2}\end{array}$ & \pm & mol molAg surf $^{-1} \mathrm{~Pa}^{-1} \mathrm{~s}^{-1}$ \\
\hline Vinyl chloride & $\begin{array}{l}9.10 \times 10^{-2} \\
9.04 \times 10^{-3}\end{array}$ & \pm & mol molAg surf $^{-1} \mathrm{~Pa}^{-1} \mathrm{~s}^{-1}$ \\
\hline
\end{tabular}

The model for predicting the chlorine coverage can be modified to incorporate mixtures of alkyl chlorides in the feedstream by including a linear combination of chloriding effectiveness $\left(\mathrm{k}_{3} \mathrm{~K}_{4} \times \mathrm{P}_{\text {alkyl chloride }}\right)$ for each alkyl chloride as depicted in equation S.6. The applicability of the modified expression of chlorine coverage is shown by comparing the experimentally measured chlorine coverages at various ethyl chloride-vinyl chloride mixture concentrations and the model predictions using the $\mathrm{k}_{3} \mathrm{~K}_{4}$ parameters values shown in Table S.2. The parity plot (Figure S.8 (b)) comparing the predicted chlorine coverage (calculated using equation S.6) with the measured chlorine coverage shows the fidelity with which the model can describe the chlorine coverage for alkyl chloride mixtures in the epoxidation feedstream.

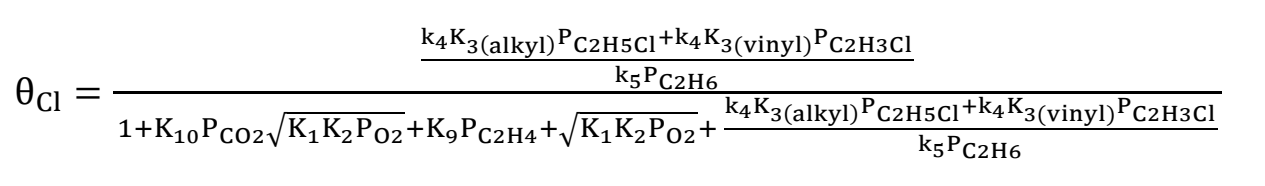



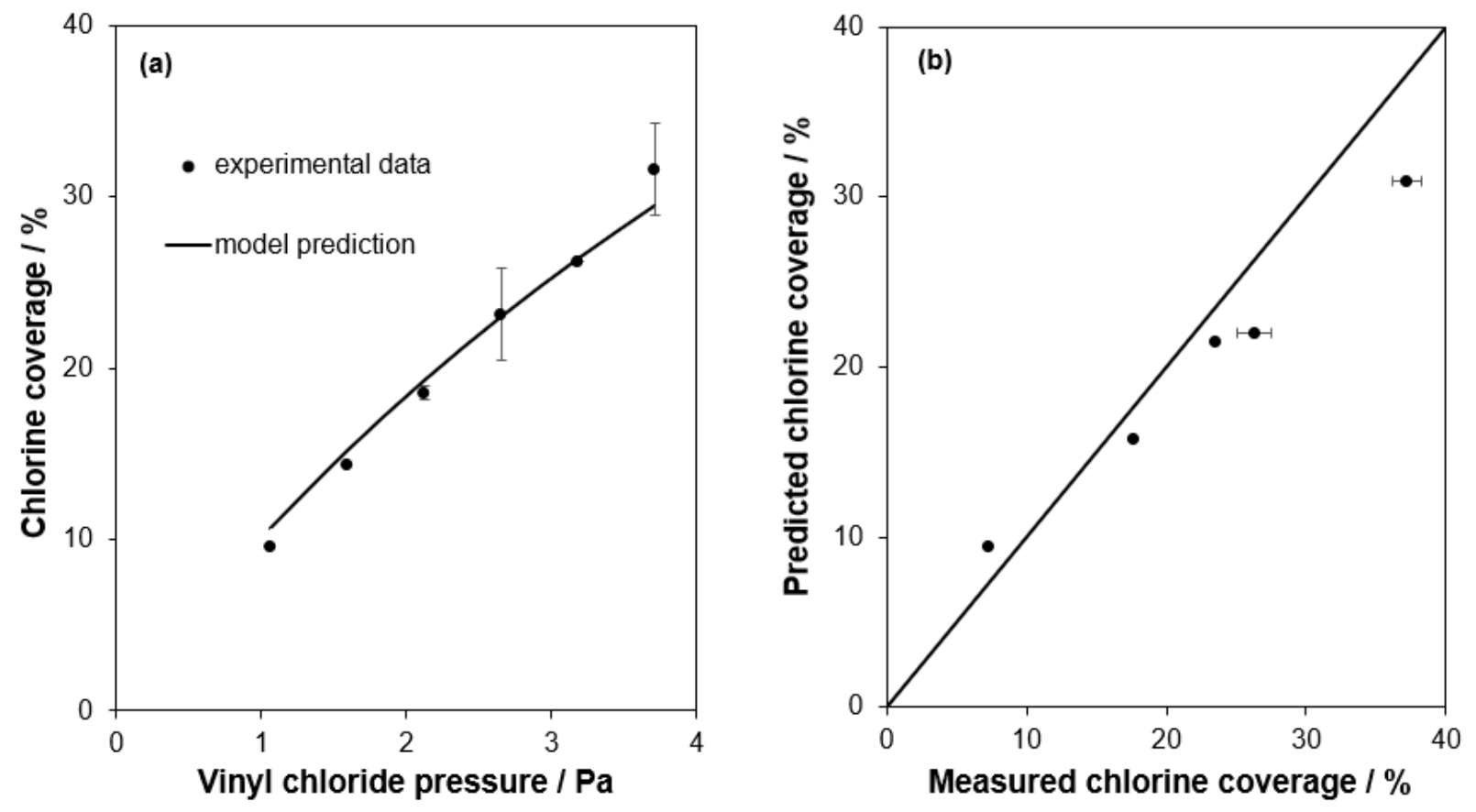

Figure S.8. (a) Chlorine coverage measured as a function of vinyl chloride pressure (Line represents the fit to the model according to Eq S.5). Each data point shown is a steady state condition acquired after $18 \mathrm{~h}$ onstream. Steady state conditions: $30 \mathrm{~mol} \% \mathrm{C}_{2} \mathrm{H}_{4}, 5.3 \mathrm{~mol} \% \mathrm{O}_{2}, 1 \mathrm{~mol} \% \mathrm{CO}_{2}, 2-7 \mathrm{ppm} \mathrm{C}_{2} \mathrm{H}_{3} \mathrm{Cl}, 0.4 \mathrm{~mol} \%$ $\mathrm{C}_{2} \mathrm{H}_{6}$, balance $\mathrm{He}$; 5.3 bar; $513 \mathrm{~K}$; space velocity $=79.37 \mathrm{~cm}^{3} \mathrm{~s}^{-1} \mathrm{~cm}^{-3}$ cat; flow rate $=2.78 \mathrm{~cm}^{3} \mathrm{~s}^{-1}$; catalyst mass $=0.035 \mathrm{~g}$ promoted $\mathrm{Ag} / \alpha-\mathrm{Al} 2 \mathrm{O} 3$, (b) Parity plot comparing the predicted chlorine coverage and measured chlorine coverage for mixtures of vinyl chloride and ethyl chloride in the epoxidation feedstream (Line represents all values where predicted chlorine coverage equals the measured chlorine coverage). Each data point shown is a steady state condition acquired after $18 \mathrm{~h}$ on-stream. Steady state conditions: $30 \mathrm{~mol} \%$ $\mathrm{C}_{2} \mathrm{H}_{4}, 5.3 \mathrm{~mol} \% \mathrm{O}_{2}, 1 \mathrm{~mol} \% \mathrm{CO}_{2}, 2-5 \mathrm{ppm} \mathrm{C} \mathrm{H}_{5} \mathrm{Cl}, 2.5-5.5 \mathrm{ppm} \mathrm{C}_{2} \mathrm{H}_{3} \mathrm{Cl}, 1 \mathrm{~mol} \% \mathrm{C}_{2} \mathrm{H}_{6}$, balance $\mathrm{He} ; 5.3$ bar; $513 \mathrm{~K}$; space velocity $=79.37 \mathrm{~cm}^{3} \mathrm{~s}^{-1} \mathrm{~cm}^{-3}$ cat; flow rate $=2.78 \mathrm{~cm}^{3} \mathrm{~s}^{-1}$; catalyst mass $=0.035 \mathrm{~g}_{\text {promoted }}$ $\mathrm{Ag} / \mathrm{\alpha}-\mathrm{Al} 2 \mathrm{O} 3$.

\section{S.8. EO degradation kinetics}

EO consumption rates are only weakly dependent on oxygen concentrations (Figure S.9)

at high EO concentrations (0.85 $\mathrm{mol} \% \mathrm{EO})$. 


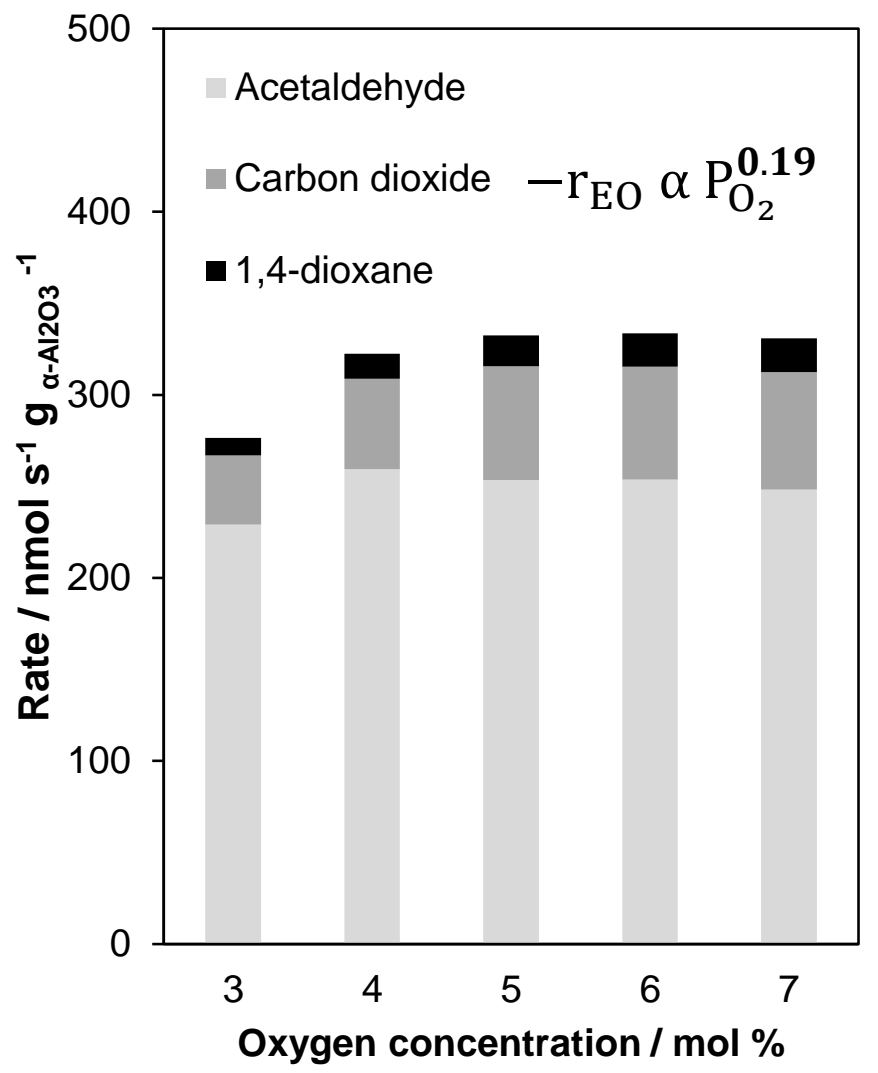

Figure S.9. Rates of different $\mathrm{EO}$ degradation products (normalized per $\mathrm{g} \alpha-\mathrm{Al}_{2} \mathrm{O}_{3}$ ) as a function of $\mathrm{O}_{2}$ concentration. Steady state conditions: $0.85 \mathrm{~mol} \% \mathrm{EO}, 3-7 \mathrm{~mol} \% \mathrm{O}_{2}, 0.4 \mathrm{~mol} \% \mathrm{H}_{2} \mathrm{O}, 4.5 \mathrm{ppm} \mathrm{C}_{2} \mathrm{H}_{5} \mathrm{Cl}, 0.4$ mol\% $\mathrm{C}_{2} \mathrm{H}_{6}$, balance $\mathrm{He}$; 5.3 bar; $513 \mathrm{~K}$; space velocity $=38.64 \mathrm{~cm}^{3} \mathrm{~s}^{-1} \mathrm{~cm}^{-3}$ cat; flow rate $=2 \mathrm{~cm}^{3} \mathrm{~s}^{-1}$; catalyst mass $=0.052 \mathrm{~g}$ promoted $\alpha$-Al2O3.

\section{S.9. Predictive model for ethylene epoxidation kinetics in a packed-bed reactor}

\section{S.9.1. Derivation of plug flow reactor model}

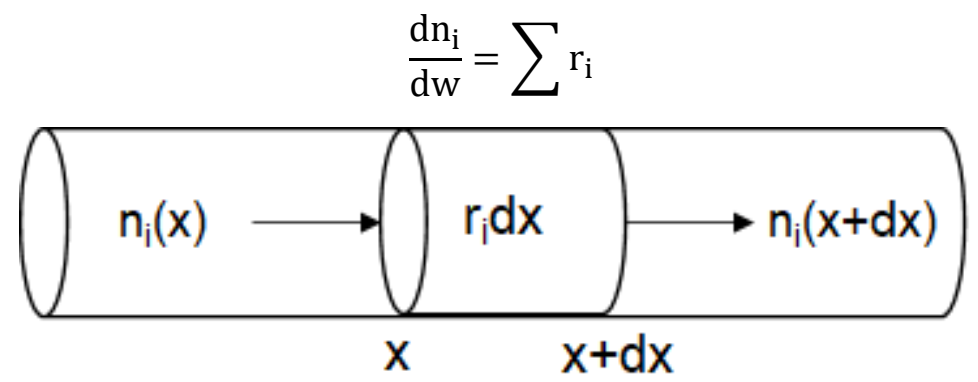

Scheme S.1. Schematic diagram of a plug flow reactor 
A plug flow reactor assumes there is complete radial mixing and no axial mixing among fluid elements. If $n_{i}(x)$ is the total moles of component $i$ entering the differential element $d x$ (containing catalyst of amount $\mathrm{dW})$ at length $\mathrm{x}$ and $\mathrm{n}_{\mathrm{i}}(\mathrm{x}+\mathrm{dx})$ is the total moles of component $\mathrm{i}$ exiting the differential element $d x$ at length $x+d x$. A mole balance on the differential length element $d x$ is as follows:

$$
\begin{array}{cc}
n_{i}(x)-n_{i}(x+d x)=d W{ }^{*} r_{i} & \text { Eq. (S.7) } \\
\frac{d n_{i}}{d w}=r_{i} & \text { Eq. (S.8) }
\end{array}
$$

If there are more than one rate process that consumes or produces component $\mathrm{i}$, the equation is modified as follows:

$$
\frac{\mathrm{dn}_{\mathrm{i}}}{\mathrm{dw}}=\sum \mathrm{r}_{\mathrm{i}}
$$

\section{S.9.2. Calculation of Peclet number}

The Peclet number which reflects the relative contributions of convective and diffusive mass transport was calculated to validate the plug flow description used in the formulation of the reactor model.

Total flowrate $(\mathrm{Q})=2.78 \mathrm{~cm}^{3} \mathrm{~s}^{-1}$, Reactor diameter $(\mathrm{D})=0.45 \mathrm{~cm}$, Bed length $(\mathrm{L})=1.48 \mathrm{~cm}$

$$
\text { Superficial gas velocity }\left(\mathrm{u}_{\mathrm{s}}\right)=\frac{\mathrm{Q}}{\frac{\pi \mathrm{D}^{2}}{4}}
$$

Superficial gas velocity $\left(\mathrm{u}_{\mathrm{s}}\right)=16.92 \mathrm{~cm} \mathrm{~s}^{-1}$

Diffusivity of oxygen in helium $\left(\mathrm{D}_{\mathrm{i}}\right)$ was used as an upper limit of gas diffusivity as $\sim 60 \%$ of the reaction mixture is composed of the inert helium. Porosity was set to 1 to calculate a lower limit of the Peclet number. 
Diffusivity $\left(\mathrm{D}_{\mathrm{i}}\right)=1.82 \mathrm{~cm}^{2} \mathrm{~s}^{-1}(7)$

$$
\mathrm{Pe}=\frac{\mathrm{u}_{\mathrm{s}} \mathrm{L}}{\mathrm{D}_{\mathrm{i}}}=13.67
$$

\section{S.9.3. Model validation - Cumulative EO selectivity}

The validity of the reactor model was determined by performing ethylene epoxidation reactions at integral ethylene conversions and by comparing the experimentally measured cumulative product selectivity with the reactor model predictions (Figure S.10).

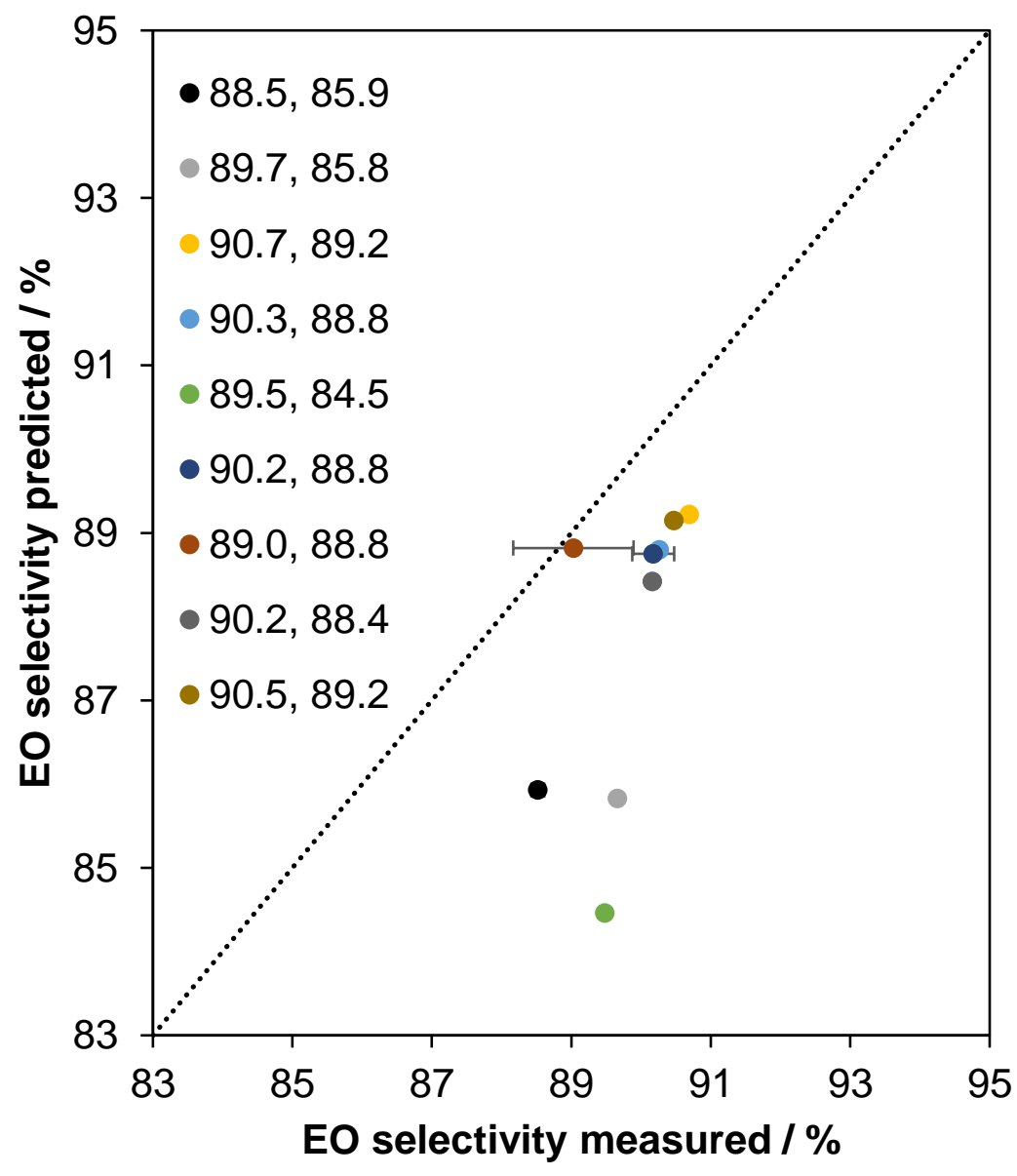

Figure S.10. Parity plot comparing the experimentally measured and predicted values of cumulative EO selectivity. Values displayed inside the figures indicate the measured and predicted values respectively. Each data point shown is a steady state condition acquired after $18 \mathrm{~h}$ on-stream. Steady state conditions: 20-40 mol\% $\mathrm{C}_{2} \mathrm{H}_{4}, 3-6 \mathrm{~mol} \% \mathrm{O}_{2}, 0.25-0.7 \mathrm{~mol} \% \mathrm{C}_{2} \mathrm{H}_{6}, 2.3-8 \mathrm{ppm} \mathrm{C}_{2} \mathrm{H}_{5} \mathrm{Cl}, 0.35-3 \mathrm{~mol} \% \mathrm{CO}_{2}$; flowrate = $2.78 \mathrm{~cm}^{3} \mathrm{~s}^{-1}$; space velocity $=10.72 \mathrm{~cm}^{3} \mathrm{~s}^{-1} \mathrm{~cm}^{-3}$ cat; $513 \mathrm{~K} ; 5.3$ bar; catalyst mass $=0.25 \mathrm{~g}_{\text {promoted Ag/a-Al203; }}$; 
ethylene conversions $=4-6 \%$. The dotted line represents all values where predicted and measured values are equal.

\section{References}

(1) Miller, J. H.; Joshi, A.; Li, X.; Bhan, A. Catalytic Degradation of Ethylene Oxide over Ag/ $\alpha-\mathrm{Al}_{2} \mathrm{O}_{3}$. J. Catal. 2020, 389, 714-720. https://doi.org/10.1016/j.jcat.2020.07.008.

(2) Woldman, N. E.; Frick, J. P. Woldman's Engineering Alloys, 9th ed.; ASM International: Materials Park, OH, 2000.

(3) Hickman, D. A.; Degenstein, J. C.; Ribeiro, F. H. Fundamental Principles of Laboratory Fixed Bed Reactor Design. Curr. Opin. Chem. Eng. 2016, 13, 1-9. https://doi.org/10.1016/j.coche.2016.07.002.

(4) Van Hoof, A. J. F.; Filot, I. A. W.; Friedrich, H.; Hensen, E. J. M. Reversible Restructuring of Silver Particles during Ethylene Epoxidation. ACS Catal. 2018, 8 (12), 11794-11800. https://doi.org/10.1021/acscatal.8b03331.

(5) Zhang, L., Liu, A. C., \& Habenschuss, M., Method of Achieving and Maintaining a Specified Alkylene Oxide Production Parameter with a High Efficiency Catalyst. US8362284, 2013.

(6) Shibata, H., Basrur, A. G., Gopal, S., Mcadon, M. H., Liu, A. C. Y., Zhang, L., \& Frank, E. R., Method of Formulating Alkylene Oxide Catalyst in Relation to Catalyst Reference Properties. US9908861B2., 2018.

(7) Wasik, S. P.; McCulloh, K. E. Measurements of Gaseous Diffusion Coefficients by a Gas Chromatographic Technique. J. Res. Natl. Bur. Stand. Sect. Phys. Chem. 1969, 73A (2), 207. https://doi.org/10.6028/jres.073A.018. 